\title{
PERANAN AKUNTANSI PENJUALAN SEBAGAI ALAT UNTUK MENINGKATKAN INFORMASI PENJUALAN PADA AGEN LPG
}

\author{
*)Ahmad Faishol \\ **) Enis Nurlaeni \\ Universitas Islam Lamongan
}

\begin{abstract}
ABSTRAKSI
Bahwa perusahaan sistem akuntansi penjualan yang diterapkan oleh perusahaan masih kurang baik dan masih kurang menjamin, adanya sistem pengendalian intern yang baik pula dan dengan adanya perangkapan tugas/jabatan oleh karyawan bagian keuangan yang juga sebagai petugas administrasi dan skretaris maka hal ini sudah merupakan suatu penyimpangan terhadap sistem pengendalian intern yang berlaku dan hal ini akan mendorong adanya suatu perbuatan yang dapat merugikan perusahaan, misalnya : penyelewengan dan akan terjadi kekeliruan dalam melakukan tugasnya.

Dan berdasarkan kesimpulan diatas, penulis dapat mengimplikasikan bahwa perusahaan harus menyempurnakan struktur organisasi agar dapat diketahui secara jelas fungsi, wewenang dan tanggung jawab masing-masing bagian serta memperbaiki sistem akuntansi penjualan yang diterapkan oleh perusahaan dengan sistem akuntansi penjualan yang baik serta didukung adanya pengendalian intern yang memadai.
\end{abstract}

Kata Kunci : Akuntansi penjualan, dan Informasi Penjualan

\section{PENDAHULUAN}

Pada setiap perusahaan pimpinan berkewajiban untuk mengetahui keadaan yang berlangsung didalam perusahaan, baik mengenai keuangan mengenai penjualanya, oleh karena banyaknya kegiatan serta aktivitas yang terjadi didalam perusahaan tersebut maka pimpinan mempunyai wewenang untuk mendelegasikan sebagaian dari tugas dan tanggung jawabnya pada para bawahannya. Agar tugas dan tanggung jawab yang diharapkan dapat tercpai dan terlaksan dengan baik, maka pimpinan berkewajiban menggunakan alat-alat yang dapat membantu untuk mengadakan pengawasan ataupun pengendalian sehingga dapat diketahui sejauh mana perkembangan dan kemajuan yang telah dicapai oleh suatu perusahaan yang dipimpinnya.

Sedangkan alat-alat yang dimaksud di sini adalah suatu sistem akuntansi yang baik, tertib dan teratur agar pengendalian intern yang diharapkan dapat tercpai, karena tujuan utama pengendalian intern adalah sebagai berikut:

- Menjaga harta milik perusahaan

- Memeriksa ketelitian dan kebenaran data perusahaan

- Memeriksa serta menekan biaya pencatatan didalam menyediakan informasi yang dibutuhkan perushaan

Tetapi pada kenyataanya banyak pimpinan perusahaan yang hanya menghendaki laporan yang tepat dan benar. Dengan keadaan tersebut diatas mengakibatkan sistem akuntansi yang mempunyai fungsi sebagai alat pengendalian intern yang dapat menjaga harta milik perusahaan serta memeriksa ketilitian dan kebenaran data akuntansi serta memajukan efisiensi dalam operasi dan membantu dipatuhinya kebijaksanaan 
manajemen yang telah ditetapkan terlebih dahulu, kurang mendapatkan perhatian.

Oleh karena itu agar apa yang diharapkan dan direncanakan dapat tercapai, maka sistem akuntansi sebagai alat pengendalian intern yang telah disusun agar dipatuhi sehingga dapat tercapai dan terpenuhi tujuan yang telah diharapkan.

Berdasarkan latar belakang diatas maka, maka dengan mengadakan penelitian pada "CV. KEDUNG KARANG" di Lamongan sebagai obyek penelitian, penulis mengambil judul:

"PERANAN AKUNTANSI PENJUALAN

SEBAGAI ALAT UNTUK

MENINGKATKAN INFORMASI
PENJUALAN PADA AGEN LPG CV. KEDUNG KARANG LAMONGAN"

\section{B. Rumusan Masalah}

Berdasarkan latar belakang diatas, maka dapat dirumuskan permasalahan sebagai berikut:

"Sejauh mana sistem akuntansi penjualan dapat meningkatkan informasi penjualan pada Agen LPG CV. Kedung Karang Lamongan?"

\section{Tujuan Penelitian}

Tujuan penelitian terdiri dari :

"Untuk mengetahui sejauh mana sistem akuntansi penjualan dapat meningkatkan informasi penjualan pada Agen LPG CV. Kedung Karang Lamongan"

\section{Kegunaan Penelitian}

a. Manfaat bagi Ilmu Pengetahuan

Dapat digunakan sebagai bahan masukkan yang bermanfaat untuk memperluas wawasan pengetahuan bagi pembaca, serta dapat menambah laporanlaporan pembuktian akan penelitian baik pada lembaga pendidikan maupun bagi perusahaan lainya.

b. Bagi Pengembalian Kebijaksanaan

Sebagai bahan perbandingan atau bahan informasi tambahan untuk meningkatkan penjualan. Juga dapat pula digunakan sebagai bahan dalam mengambil keputusan dimasa yang akan datang.

c. Manfaat bagi Peneliti
Sebagai bahan perbandingan antara teori-teori yang pernah penulis terima dibangk kuliah dengan praktek yang sebenarnya terjadi.

d. Manfaat bagi Universitas

Dapat menambah bahan serta untuk mengisi perpustakaan guna untuk manfaat penelitian bagi generasi yang akan datang.

\section{METODE PENELITIAN}

\section{Jenis Penelitian}

Jenis penilitian adalah penilitian secara deskripsi, selanjutnya akan dibuat deskripsi/gambaran secara sistematis mengenai sifat akutansi penjualan sebagai alat untuk meningkatkan informasi penjualan

\section{Teknik Penarikan Sampel}

\section{Populasi}

Menurut Sujoko Effrin (2008)

Populasi adalah merupakan batas dari suatu obyek penelitian dan sekaligus merupakan batas bagi proses induksi dari hasil penelitian yang bersangkutan.

Dari beberapa pengertian di atas dapat disimpulkan bahwa populasi penelitian adalah keseluruhan obyek yang akan diteliti. Populasi dalam penelitian ini adalah akuntansi penjualan, meningkatkan informasi penjualan tahun 2012-2014.

\section{Sampel}

Menurut Sujoko Effrin (2008)

Sampel adalah bagian dari populasi yang memenuhi syarat untuk dijadikan sebagai obyek penelitian.

Sedangkan sampel penelitian adalah sebagian dari populasi yang akan diteliti yang mewakili seluruh populasi. Adapun yang digunakan dalam penelitian ini adalah informasi penjualan pada CV. Kedung Karang di Lamongan.

\section{Sumber Data}

Dalam melaksanakan penelitian CV. Kedung Karang tentang peranan sistem akuntansi penjualan sebagai alat untuk meningkatkan informasi penjualan maka data-data yang dipergunakan penulis dibedakan menjadi beberapa kelompok yaitu : 
1) Data Primer

Yang dimaksud dengan data primer adalah data yang diperoleh langsung dari pihak yang berwenang dalam perusahaan yaitu pimpinan perusahaan.

2) Data Sekunder

Data yang diperoleh peneliti dari instansi-instansi yang terkait dan mempelajari literatur-literatur yang ada hubunganya dengan permasalahan yang penulis sajikan.

E. Cara Pengumpulan Data

1) Library Research

Yaitu cara pengumpulan data secara teoritis sebagai bahan perbandingan dengan jalan mengadakan pengumpulan data-data yang diperoleh dari buku-buku perpustakaan yang ada hubunganya dengan masalah yang akan diteliti.

2) Field Research

Yaitu pengumpulan data dimana dilaksanakan dengan jalan mengadakan penilitian terhadap obyek secara langsung, adapun cara pengumpulanya dengan cara :

\section{Interview}

Yaitu yang digunakan untuk mengumpulkan data dengan jalan mengadakan komunikasi secara langsung, atau hanya tanya jawab kepada orang yang ada diperusahaan.

\section{Observasi}

Yaitu cara pengumpulan data dengan jalan mengadakan pengamatan di dalam lingkungan perusahaan, yang mempunyai hubungan dengan masalah yang akan diteliti.

\section{Dokumentasi}

Yaitu cara pengumpulan data dengan melakukan penelitian terhadap dokumen atau file-file masa lalu yang ada dalam perusahaan, seperti catatan produksi dan catatan penjualan.

\section{F. Definisi Operasional Variabel}

1) Definisi Operasional

Definisi operasional memuat definisi variabel secara operasinonal yaitu diantaranya adalah sebagai berikut :
a) Variabel Bebas / Independent Variabel $(\mathrm{X})$

Variabel Bebas adalah merupakan variabel yang mempengaruhi atau yang menjadi sebab perubahannya atau timbulnya variabel terikat/dependent (Sugiono,2008:39), dalam penelitian ini ang termaksud didalam variabel independent adalah :

Penjualan

yaitu merupakan kegiatan yang dilakukan oleh penjual dalam menjual barang atau jasa dengan harapan akan memperoleh laba dari adanya transaksitransaksi tersebut dan penjualan dapat diartikan sebagai pengalihan atau pemindahan hak kepemilikan atas barang atau jasa dari pihak penjual ke pembeli."

b) Variabel Terikat / Dependent Variabel (Y)

Variabel Terikat adalah variabel yang dipengaruhi atau yang menjadi akibat karena adanya variabel bebas (Sugiono, 2008:39), dalam penelitian ini ang termaksud didalam variabel dependent adalah :

\section{$\square \quad$ Informasi penjualan}

Y aitu informasi yang dihasilkan dari sistem akuntansi penjualan, dapat berupa laporan sejenis produk, daerah pengiriman barang dll, yang berguna bagi manajer penjualan untuk pengambilan keputusan.

G. Metode Analisa Data

Pada sumber data tersebut, bahwa dalam pelaksanaan penelitian ini datanya bersumber dari perusahaan yang bersifat kualitatif. Karena sifat data yang demikian, maka penulis dalam menganalisa menggunakan metode analisa data yang bersifat non statistik, yaitu dengan membaca atau membuat daftar

Sistem akuntansi penjualan yaitu merupakan bagian dan formulir serta catatan yang ada dalam perusahaan, semuanya itu harus ada pemisahan fungsi yaitu fungsi penyimpanan dan oprasional harus dipisahkan dari fungsi akuntansi sehingga tujuan pengendalian intern dapat tercapai.

penjualan dengan menggunakan angkaangka yang tersedia kemudian melakukan uraian. Adapun analisa yang digunakan 
dalam penelitian ini adalah $: \bullet$ Metode Analisa kualitatif

Adalah analisis yang digunakan untuk penelitian tentang kehidupan masyarakat, sejarah, tingkah laku, fungsionalisasi organisasi, aktivitas sosial, dan lain-lain. Salah satu alasan menggunakan pendekatan kualitatif adalah pengalaman para peneliti dimana metode ini dapat digunakan untuk menemukan dan memahami apa yang tersembunyi dibalik fenomena yang kadangkala merupakan sesuatu yang sulit untuk dipahami secara memuaskan.

\section{PEMBAHASAN}

Dalam hal pembahasan pada halaman ini akan dijelskan dengan metode kualitatif, dimana metode kualitatif mempunyai pengertian sebagai suatu analisa data dengan memberikan uraian uraian yang sesuai dengan kenyataan dan keadaan yang sebenarnya terjadi pada obyek penelitian.

\section{a. Permasalahan}

Pada setiap perusahaan baik yang sudah berkembang dengan pesat maupun perusahaaan yang baru berdiri tentu menghadapi permasalahn-permasalahan. Sedangkan permasalahan yang terjadi di perusahaan itu semata-mata ada yang besar dan data yang kecil, ada yang datang dari luar dan ada yang datang dalam perusahaan itu sendiri.

Sudah barang tentu permasalahan yang ada harus segera dicarikan jalan keluar agar tidak menimbulkan akibatakibat yang diinginkan. Sebelum penulis mengadakan peninjauan lebih lanjut pada permasalahan yang sedang dihadapi oleh perusahaan maka terlebih dahulu akan penulis kemukakan tujuan jangka pendek yang telah ditentukan terlbih dahulu, atau dapat diterapkan serta segera dicapai dalam waktu kurang dari satu tahun atau relatif pendek.

Adapun permasalahan yang penulis kemukakan dalam perusahaan ini adalah sejauh mana sistem akuntansi dapat meningkatkan informasi penjualan pada agen LPG di Lamongan.

b. Sebab-sebab Masalah

Yang menjadi penyebab timbulnya permasalahan tersebut seperti telah diketahui dalam suatu perusahaan terdapat petugas/karyawan yang merangkap jabatan maka hal ini jelas merupakan suatu kelemahan dalam sistem pengendalian intern perusahaan tersebut, karena dalam sistem pengendalian yang baik terdapat suatu pemisahan tanggung jawab fungsional secara tepat demi untuk menjaga milik perusahaan.

\section{c. Akibat Masalah}

Selanjutnya dengan adanya sebabsebab tersebut diatas akan dapat mengakibatkan :

1. Adanya penyimpangan dari garisgaris kebijaksanaan yang telah ditentukan. Yang penulis maksud disini adalah kemungkinan terjadinya korupsi dan manipulasi yang dapat terjadi karena kurang banyaknya delivery order, bukti serah terima barang dan tidak adanya kartu kontrol persediaan kantor, juga korupsi dan manipulasi ini dapat terjadi dikarenakan adanya petugas yang merangkap jabatan yaitu selain sebagai tugas sub bagian keungan juga merangkap sebagai petugas sub bagian administrasi/pembukuan. Oleh karena itu kegiatan-kegiatan yang ada dalam perusahaan haruslah tergambar dalam pola organisasi. Ini berarti bahwa dengan adanya suatu pengawasan, maka penyimpangan ang terjadi dapat ditunjukkn pada pola organisasi yang bersangkutan. Pelaksanaan pengendalian intern adalah merupakan alat yang sangat baik untuk membantu manajemen dalam mengamankan harta kekayaan milik

perusahaan, menambah efisiensi kerja dan mendorong ditaatinya ketentuan yang berlaku diperusahaan.

2. Tujuan dari perusahaan belum dapat tercapai dengan baik, artinya apabila permasalahan yang ada dalam perusahaan itu tidak segera dipecahkan, maka target penjualan yang telah ditetapkan oleh 
perusahaan tidak akan tercapai dengan baik.

\section{d. Alternatif Pemecahan Masalah}

Alternatif-alternatif yang dapat penulis usulkan dalam pemecahan masalah ini adalah sebagai berikut :

1. Apabila formulir yang ada diperusahaan dapat diperbanyak dan dapat dipergunakan sebagai mana mestinya maka akan dapat menjaga terjadinya korupsi dan manipulasi yang mengakibatkan penurunan dan kerugian penjualan pada perusahaan, juga akan terjadi kesalah fahaman antara pegawai dan pimpinan, dimana formulir atau bukti serah terima barang dan kartu kontrol persediaan kantor meupakan alat untuk mengetahui perkembangan penjualan/serta mengetahui data-data penjualan dalam upaya meningkatkan pengendalian intern penjualan.

2. Memindahkan fungsi perangkapan tugas dimana bagian keungan harus dipisahkan diri bagian administrasi, apabila setiap bagian tersebut dipisahkan menurut fungsinya maka masing-masing sesuai bagiannya maka apa yang diharapkan oleh pimpinan dapat tercapai

e. Pemecahan Masalah

Sudah sewajarnya apabila suatu perusahaan mempunyai suatu permasalahan, baik permasalahan itu datangnya dari luar maupun dari dalam perusahaan. Dan sudah barang tentu permasalahan yang ada perlu dicari jalan keluarnya. Untuk mendapatkan suatu pembenahan, agar usahanya dapat berhasil sesuai dengan yang telah direncanakan sebelumnya.

Dan apabila permasalahan tersebut tidak segera ditanggulangi maka jelas akan mengahambat tercapainya tujuan dari perusahaan. Adapun langkah-langkah yang perlu diambil oleh perusahaan dalam memecahkan suatu permasalahan yang dihadapi sebagai berikut :

1. Memperbaiki sistem akuntansi yang ada, yaitu dengan memperbanyak order, bukti serah terima barang dan mengadakan kontrol atau mengadakan kartu kontrol persediaan kantor. Artinya apabila perusahaan masih menerapkan sistem akuntansi yang selama ini dipakai maka sampai kapanpun tujuan dari pada sistem akuntansi harus memperhatikan unsurunsur yang erat kaitannya dengan sistem akuntansi yaitu adanya formulir, bukubuku, alat-alat, catatan dan metode yang digunakan untuk mengolah data yang berhubungan dengan usaha suatu perusahaan dengan tujuan untuk menghasilakan umpan balik dalam bentuk laporan-laporan yang diperoleh yang diperlukan oleh manajemen untuk mengawasi usahanya dan bagi pihak-pihak lain yang berkepentingan seperti PT. Pertamina dan lembaga-lembaga pemerintahan untuk menilai hasil operasi perusahaan.

2. Memperbaiki struktur organisasi yang ada pada perusahaan masih kurang baik karena terdapat bagian yang tidak terpisah, yaitu pada bagian sub keuangan/administrasi maka hal ini jelas merupakan suatu kelemahan yang sangat besar dalam suatu perusahaan, dan apabila hal tersebut tidak segara diperbaiki maka sudah barang tentu sangat menghambat tercapainya tujuan dari perusahaan. Jadi jelaslah bahwa struktur organisasi adalah juga merupakan hal yang sangat penting bagi perusahaan didalam mencapai tujuan yang teleh ditetapkan. Dan oleh sebab itu penulis berusaha membuat suatu struktur organisasi yang baik dan jelas, gambar organnisasi tersebut dapat dilihat pada halaman setelah prosedur penjualan yang benar menurut penulis.

\section{f. Asumsi}

Asumsi yang dapat penulis ambil dalam pembahasan ini adalah sebagai berikut :

1. Proses melakukan isi ulang gas.

2. Karyawan perusahaan cukup

3. Dana untuk menggaji karyawan jumlahnya memadai

4. Keadaan perusahaan stabil

Berdasarkan pembuktian hipotesa yang telah diajukan penulis dalam menghadapi masalah yang dapat dibuktikan kebenaranya berdasarkan teori- 
teori yang ada maka terbuktilah pembuktian hipotesa sebagai berikut :

1. Sistem Akutansi

Apabila sistem akuntansi yang ada pada Agen LPG $3 \mathrm{Kg}$ " Lamongan diperbaharui maka diharapkan informasi penjualan dapat meningkat sesuai dengan apa yang telah digariskan oleh pimpinan. Sistem akuntansi yang baik, tertib dan teratur ialah dengan apa yang telah ada pada pengertian sistem akuntansi ialah apabila semua bagian-bagian diatas dipenuhi maka ihal manajemen dapat mengontrol atau mengawasi usahanya serta tidak adanya penyelewengan-penyelewengan yang terjadi pada perusahaan serta diharapkan apabila semua berjalan dengan baik, serta tertib penjualannya dapat meningkat.

2. Pengendalian Intern

Sesuai dengan pengertian pengendalian intern yang meliputi struktur organisasi dan semua cara-cara serta alat-alat yang dikoordinasikan dan digunakan dalam perusahaan dengan tujuan untuk menjaga keamanan harta milik perusahaan, memeriksa ketelitian dan kebenaran data akuntansi, memajukan efisiensi dalam operasi dan membantu menjaga dipatuhinya kebijaksanaan manajemen yang telah ditetapkan lebih dahulu dengan mengingat ciri-ciri dari sistem pengendalian intern agar dilakukan pemisahan fungsi yang tepat sesuai dengan tugas dan tanggung jawanya sehingga terdapat pemisahan antara fungsi pencatatan, penyimpanan dan pengawasan dengan tujuan untuk menjaga harta milik perusahaan, maka jelaslah bahwa perusahaan yang belakangan ini sering mengalami penurunan tingkat penadapatannya serta adanya kerugiankerugian lain yang belum atau yang sudah diketahui oleh pimpinan perusahaan karena, bagian keuangan juga merangkap bagian administrasi dan sekretaris. Dengan adanya perangkapan fungsi ini maka pekerjaan yang dilakukan tidak ada kontrol dari bagian lainnya, sehingga kecurangankecurangan dapat dengan mudah dilakukan, untuk memenuhi syarat bagi adanya suatu pengendalian intern yang baik bagi perusahaan maka bagian keuangan tidak boleh merangkap bagian administrasi dan skretaris dengan demikian maka pekerjaan dari bagian yang satu akan terkontrol oleh bagian yang lainnya secara otomatis.

3. Memperbaiki prosedur penjualan

a. Bagian-bagian pejualan menerima pesenan dari pembeli. Atas dasar pesanan ini dibuat surat perintah pengiriman rangkap 3. Masing-masing tembusan mempunyai fungsi sebagai berikut :
Lembar 1 : Order
Lembar 2 : Bukti pengiriman
Lembar 3 : Arsip
Penjelasan :

1. Lembar 1 yaitu bagian dari surat perintah pesanan buat mengirim suatu barang ke pelanggan.

2. Lembar 2 yaitu di serahkan ke pelanggan sebagai tanda bukti pengiriman barang.

3. Lembar 3 yaitu di simpan sebagai arsip atau bukti penjualan.

b. Bagian buku penjualan mencatat jumlah pengambilan barang, kemudian setiap 1 bulan sekali di buat sebuah laporan penjualan.

c. Setiap bulan laporan penjualan harus memenuhi target yang sudah ditentukan.

\section{KESIMPULAN DAN SARAN KESIMPULAN}

Setelah penulis mengutarakan tentang apa dan bagaimana cara serta jalan untuk mengatur pelaksanaan sistem akuntansi penjualan sebagai alat untuk meningkatkan informasi penjualan efektif maka dengan ini penulis akan memberikan beberapa kesimpulan dan kesimpulan tersebut atas dasar pertimbangan yang didukung oleh teori sehubungan dengan permasalahan yang ada pada perusahaan. Adapun kesimpulan-kesimpulan yang penulis kemukakan adalah sebagai berikut

Dengan diterapkannya sistem akuntansi penjualan LPG di Lamongan diharapkan 
dapat diperbaiki memperluas informasi yang dibutuhkan.

1. Adanya perangkapan fungsi dan tugas karena pimpinan tidak mengadakan pembagian wewenang dan tanggung jawab yang tepat sehingga masih ada satu bagian yang mengerjakan dua rangkaian pekerjaan sekaligus.

2. Dengan memperbanyak formulir formulir serta memberikan bukti serah terima dan membuat jadwal pengiriman yang sesuai.

3. Sistem akuntansi penjualan yang diterapkan oleh perusahaan masih kurang baik dan masih kurang menjamin adanya sistem pengendalian intern yang baik pula serta memperbaiki prosedur penjualan.

4. Apabila sistem akuntansi dilaksanakan dengan baik maka akan lebih meningkatkan informasi penjualan di perusahaan sesuai dengan apa yang diharapkan oleh pimpinan.

5. Apabila perangkapan fungsi karyawan dipisahkan menurut bagiannya masing-masing, maka akan lebih meningkatkan pengendalian intern penjualan dan tidak adanya saling kesalah fahaman antar bagian.

\section{SARAN}

Dengan memperhatikan kelemahankelemahan yang terdapat pada perusahaan maka penulis akan berusaha memberikan saran yang diperlukan untuk meningkatkan efektifitas usaha perusahaan khususnya dalam sistem akuntansi penjualan untuk meningkatkan informasi penjualan baik secara kredit maupun secara tunai, agar tujuan dari perusahaan dapat tercapai dengan baik.

Sedangkan saran-saran yang dapat penulis kemukakan adalah sebagai berikut

1. Menyempurnakan struktur organisasi yaitu dengan menambah sub bagian skretaris dan sub bagian adminitrasi sehingga dapat diketahui secara jelas fungsi, wewenang dan tanggung jawab masing-masing bagian.
2. Memperbaiki sisem akuntansi penjualan yang diterapkan oleh perusahaan dengan sistem akuntansi penjualan yang baik serta didukung adanya pengendalian intern yang memadai.

3. Sebaiknya perusahaan membentuk suatu staf audit intern yang berfungsi sebagai staf pengawas terhadap jalannya aktivitas usaha dan posisi finansial perusahaan.

\section{DAFTAR RUJUKAN}

Prof.Dr.Winwin Yadiati,S.E.,M.si.,Ak. \& Ilham Wayudi, S.E.,M.Si.

Pengantar Akutansi, Edisi Revisi Cetakan Ketiga, Jakarta Kencana Prenada Media Group 2010

Sugiyono

(2009:

http://gultomhans.wordpress.com/20

13/06/10/hipotesis-penelitian-2/

Sujono Effrin. Metode Penelitian Akuntansi, Edisi Cetakan Pertama 2008, Graha Pena Candi Gerbang Permai Blok R/6 Yogyakarta 55511

Sugiono, 2008. Metode Penelitian Bisnis, Penerbit Alfabeta, Bandung.

Zaki Baridwan, Sistem Akuntansi Penyusunan Prosedur dan Metode, edisi kelima, Bagian Penerbit Akademi Akuntansi YKPN, Yogyakarta Gajah mada University Press, 2007

D. Hartonoi, Akutansi untuk Usahawan, Edisi Kelima Lembaga Penerbit Fakultas Ekonomi Universitas Indonesia, 2005

Drs. Sukamto, Msc, Internal Control, Yayasan Badan Penerbit Gajah Mada, Yogyakarta.

Robert N. Anthony and Jhon, Manajemen Control System, Terjemahan Ir. Agus Maulana, 5th edition, Richard D. Irwin., Inc., Homewood Illionis, 2007

Bambang Hartadi. Sistem Pengendalian Intern, Dalam Hubungannya dengan Managemen dan Audit, 
edisi 5, Lembaga Penerbit FE. UI. 2006

Sugiarto dan Placidus Sudibyo, Sistem Akuntansi dan Permasalahannya, edisi sepuluh, BPFE Yogyakarta 2005

Ikatan Akuntansi Indonesia, Prinsip Akuntansi Indonesia, 2007

Ikatan Akuntansi Indonesia, Norma Pemeriksaan Akuntansi PT. Ictiar Baru Van Hoeve, Jakarta 2008

Norman Taufiq, 2013. "Hubungan Antara Peranan Akuntansi Penjualan Sebagai Alat Untuk Meningkatkan Informasi Penjualan Pada CV. Cahaya di Surabaya", Universitas Yos Soedarso Surabaya. 